\title{
Gender Politics and Social Class in Atwood's Alias Grace Through a Lens of Pronominal Reference
}

\author{
Prof. Claudia Monacelli (PhD)
}

Faculty of Interpreting and Translation, UNINT University, Rome, Italy

Doi:10.19044/esj.2018.v14n35p150 URL:http://dx.doi.org/10.19044/esj.2018.v14n35p150

\begin{abstract}
In 1843, a 16-year-old Canadian housemaid named Grace Marks was tried for the murder of her employer and his mistress. The jury delivered a guilty verdict and the trial made headlines throughout the world. Nevertheless, opinion remained resolutely divided about Marks in terms of considering her a scorned woman who had taken out her rage on two, innocent victims, or an unwitting victim herself, implicated in a crime she was too young to understand. In 1996 Canadian author Margaret Atwood reconstructs Grace's story in her novel Alias Grace. Our analysis probes the story of Grace Marks as it appears in the Canadian television miniseries Alias Grace, consisting of 6 episodes, directed by Mary Harron and based on Margaret Atwood's novel, adapted by Sarah Polley. The series premiered on CBC on 25 September 2017 and also appeared on Netflix on 3 November 2017. We apply a qualitative (corpus-driven) and qualitative (discourse analytical) approach to examine pronominal reference for what it might reveal about the gender politics and social class in the language of the miniseries. Findings reveal pronouns ' $\mathrm{I}$ ', 'their', and 'he' in episode 5 of the miniseries highly correlate with both the distinction of gender and social class. These patterns of repetition are indicative of the discourse structure of the TV miniseries Alias Grace.
\end{abstract}

Keywords: Gender, Social Class, Pronominal Reference, Margaret Atwood, TV Series

\section{Introduction}

In 1843, a 16-year-old Canadian housemaid named Grace Marks was tried for the murder of her employer and his mistress. The jury delivered a guilty verdict and the trial made headlines throughout the world. Nevertheless, opinion remained resolutely divided about Mark in terms of considering her a scorned woman who had taken out her rage on two, innocent victims, or an unwitting victim herself, implicated in a crime she was too young to understand. Marks spent the successive 30 years in various jails and asylums. 
In 1996 Margaret Atwood reconstructs Grace's story in her novel Alias Grace. Her unsettling portraits of 19th century prison and asylum life are meticulous in their detail. Atwood also introduces Dr. Simon Jordan, a physician who was retained to assess her degree of madness, who listens to the prisoner's tale with both sympathy and disbelief (Atwood 1996: 4). Victorian ideology did not allow for women's voices to be heard and in Atwood's novel Grace is found guilty of murder in the court of public opinion. Yet, she is given to opportunity to find her voice during her sessions with Dr. Jordan who affords her the opportunity of freedom through the narration of events surrounding the murder.

Atwood's novel examines issues of gender and class roles, identity, truth, and the nature of memory. For example, Dr. Jordan uses every advantage and privilege granted to him by his class, gender, and profession to protect and rescue himself from a difficult, and morally questionable, situation in relation to Grace. He becomes inextricably entwined to her 'story' and is fascinated by Grace to the point of erotic fantasizing. He then, literally, runs away, when unable to discern whether she is true to her story or whether she, indeed, is guilty. Much like the Atwood novel, the miniseries uses quilting as a dominant metaphor for the condition of women and their activities: female labor, domesticity, patchwork pieces that fit together to make a bigger picture, symbolic images, and how to tell a story. It is appropriate that Grace's own mind would be made up of separate pieces, and that the solution to the mystery of her guilt could only be visible when you step back and look at all the discrete parts that make up who she Grace Marks really is.

Our analysis probes the story of Grace Marks as it appears in the Canadian television miniseries Alias Grace directed by Mary Harron and based on Atwood's novel, adapted by Sarah Polley. The series premiered on CBC on 25 September 2017 and also appeared on Netflix on 3 November 2017. We need to acknowledge that when storytelling is transferred from one medium to another, inevitably the basic issue of whether rendition in the other medium results as being 'faithful' to the source arises and we question whether something is lost in the process. In his Novels into Film, George Bluestone (2003) discusses issues of difference in audience perception of cinematic and literary forms, stemming from the differences in their raw materials. He distinguishes the effect a camera has on our visual perception, along with the fundamental role of editing in the process of adaptation (ibid.: 20). Bluestone also hones in on the two media's ability to manage time and space and defines language as a medium consisting of "three characteristics of time - transience, sequence and irreversibility" (ibid.: 49), but in film "the camera is always the narrator, we need concern ourselves only with the chronological duration of the viewing and the time-span of narrative events" (ibid.: 49). Further, In terms of audience reception, we rather espouse the view put forward by Garzone 
(2002) who suggests looking beyond the texts or the situation in which the texts are framed and using norms as a principle to assess text reception. She goes on to distinguish norms as "internalised behavioral constraints which govern [...] choices in relation to the different contexts" (ibid.: 110). She clarifies that this definition of norms has its counterpart in text reception and reminds us that users' expectations can also be seen as norm-based. She stresses that the concept of norms can be used as a guide, not necessarily as regularities to be extracted from texts, but as prevailing normative and cognitive expectations.

For the purposes of this analysis, our view is simply based on the fact that a good majority of TV viewers may not have ever read Margaret Attwood's novel and that fact alone brings with it the expectation that - at the very least - what we view on screen would be the suggestion of a period piece whose context would portray credible themes as backdrop for the main protagonist's plight, without necessarily ever even considering that what we are viewing is the end product of an adaptation from another medium. This ensues in the spirit of entertainment. That said, ours is indeed a study and we shall side with Desmond and Hawkes (2015: 39) in considering that "...the story is the what in the narrative that is depicted, discourse is the how". As a point of reference, we here intend to examine the discourse in the TV miniseries Alias Grace.

In previous work, we have found that patterns of repetition point to the discourse structure of a text (Monacelli 2004, 2018b). In line with this, we have observed the emergence of repetitive patterns of pronouns, that - we will argue - distinguish the discourse structure in this TV series. We first introduce our corpus, methodology and analytical tools (\$2), then discuss Margaret Atwood's contribution to a discussion of gender politics in Alias Grace ( 33$)$. We review our findings $(\$ 4)$ and conclude our work with a discussion and concluding remarks $(\$ 5)$.

\section{Corpus, methodology and analytical tools}

Our corpus is comprised of both transcripts and audiovisual content of the TV miniseries Alias Grace which consists of six episodes. We use the corpus manager and analysis program Sketch Engine to seek single- and multiword keyness to understand whether this has an impact on the use of pronominal reference (e.g. Groom 2010, Stubbs 2010). The meaning of keywords and their keyness (Bondi 2010) derives from comparative quantitative corpus analysis, which identifies words which are statistically prominent in particular texts and text collections (ibid.: 22). Pronominal reference is thus quantitatively detected in texts in order to assess what it may reveal in relation to events unfolding in the miniseries narrative that specifically relate to issues of gender politics and social class. 


\subsection{Pronominal reference}

The use and meaning of pronouns in discourse is influenced by the social 'spaces' within which people and groups are positioned or position themselves (Chilton and Schäffner 1997). Pronouns can be used to indicate or obscure collectivity and individuality (Fairclough 2003), to include and exclude the audience, to refer to 'self' or 'others', or as a means of polarization between in-groups and outgroups (Van Dijk 2001).

Pronominal reference or 'indexical expressions' need be considered within their context in order to understand what intention is being conveyed. In a process of 'pronominal scaling', Chilton (2004: 58) uses a threedimensional approach to deictically indicate a person's position in a spatial axis:

The speaker (Self, which may be $I$ or a we-group) is at here. The entities indexed by second-person and third-person pronouns are "situated" along $s$, some nearer to, some more remote from self. It is not that we can actually measure the 'distances' from Self; rather, the idea is that people tend to place people and things along a scale of remoteness from the self, using background assumptions and indexical clues. (original emphasis)

The use of pronominal choices could thus determine physical distance or closeness to the speaker, but they can also be used metaphorically and "create alignments between talkers and their topics and their hearers" (Malone 1997: 58). Looking at first person pronouns ' $\mathrm{I}$ ' and 'we' is of interest because they indicate who the speaker identifies with: inclusive vs. exclusive 'we' because it has the power to include and exclude the audience; 'us' vs. 'them' because they can separate the 'self' from 'other'. The second person pronoun 'you' could refer specifically to someone or, as a generic pronoun, it can be used in a very general way referring to anyone. Third person pronouns are used as an exclusive strategy for other-presentation where 'they' is used to create an image of 'other', to divide people in groups, sometimes with a negative connotation, and to distance the 'self' from 'others', to completely avoid responsibility by distinguishing an 'us' vs. 'them' separation.

\subsection{The relevance of stance in this study}

My concern in analyzing stance, i.e. a speaker's discoursal position, is to examine their focus of attention and the shift of this focus during talk, in order to discern interactional moves. In this sense pronouns are deictic expressions and identify both humans and objects within and without the immediate speech situation. These forms of deictic reference, therefore, are analyzed in this paper primarily for what they can tell us about the shifting focus of social identity. In discussing reference-switching Hatim and Mason (1997: 114) list the effects caused by pronominal reference switching, among 
them to "relay a more supportive attitude and thus establish intimacy by, for example, involving the receiver in the communicative act". It is along these lines that moves are considered when shifts are effected in order to establish distance-altering alignments, since deictic reference encodes relations between an origo, or the deictic center in a speech event, and the intended referent.

Ting-Toomey and Kurogi (1998: 196-7) argue for a distinction between 'I-identity' and 'We-identity' facework when using first-person pronouns, which derives from the difference between independent selfconstrual [I-identity] and interdependent self-construal ['We-identity']. Further insight into the nature of pronominal reference is gained from Fillmore's lectures on deixis (1997: 5-26). He discusses the ambiguous nature of the English pronoun 'we'. According to our general knowledge of permission-granting situations, for example, the person having authority is distinct from the person seeking permission, hence the meaning potential of 'we' used when seeking permission could only indicate the inclusion of the speaker and those seeking permission, and the exclusion of the person/s having authority. The same reasoning could also be extended to situations where speakers use 'we' to distinguish one social group from another or to signal contrast.

\section{Atwood's contribution to a discussion of gender politics in Alias Grace}

For all intents and purposes, we might characterize women's lives are 'messy'. Women live in what may be considered chaos, with a constant flux of bodily processes like weight gain/loss, abortion and all other functions that women, young women in Margaret Atwood's novels, are taught to control. This very nature of women's lives distinguishes both their role and consequently their domain of power. Women's power is that of the tribe, while power relegated to males is synonymous with patriarchy, science or a form of order. However, Atwood turns to other definitions of power, precisely to combat typical patriarchal oppression as represented in her writing. To serve patriarchy, she suggests in her work, is to be seduced by power as defined in male terms, and all that comes with it: a 'position', recognition, fame, and the like, but which ultimately even mark women's downfall. Pratt claims (1981: 142) that "[w]omen's rebirth journeys create transformed, androgynous, and powerful human personalities out of socially devalued beings and are therefore more likely to involve denouements punishing the quester for succeeding in her perilous, revolutionary journey". This notion also finds a voice in Susan Sontag (1977: 31), albeit with a slightly different slant: "Sadness made one 'interesting'. It was a mark of refinement, of sensibility [...] to be powerless [...]. The melancholy character [like Keats] was a superior one!". Sontag herself brings this into notice as a 'romantic myth', one that has a form of 
refinement. We can surely define Grace Marks, the protagonist of Alias Grace, as being somewhat sad due to her fate, but also a woman who - throughout the development of the storyline - repeatedly makes reference to cultural refinement as a reflection of a woman's demeanor.

Ingersoll (2001: 386) reminds us that throughout the years a generation of theorists have stressed that gender is culturally constructed, rather than established by differences of sex or biology, citing French writers the likes of Julia Kristeva and Luce Irigaray, the latter reading gender differences in Lacan's writings. Furthermore, Irshad and Gaur (2013: 118) suggest that gender is not only a social and cultural product but it also varies according to other distinguishing features such as class, ethnicity, sexuality, and other issues concerning identity. They propose that Atwood's narrative in Alias Grace goes beyond the limits of fixed categories for both gender and genre and bestows on Grace Marks the power to express and 'reconstruct' herself by narrating her story, as she does to Dr. Jordan who is tasked with establishing whether Grace is indeed mad. This expedient - her narration - concedes that she be given a voice where, traditionally, she would have been silenced. It is thus her perceived madness that offers her the key to her own liberation from "a constructed gendered identity [that] reduces Grace to the status of passive, inferior, fragile and weaker sex and permits her no voice of protest" (ibid.: 120). Through her performance, Grace took on traits associated with her gender and class but later learned both the manners and attitude of upper-class society. With her novel Atwood explored the notion that gender, sex and class are all "the outcome of socio-cultural constructions that are handed to us through discourse. Grace Marks is able to fight against patriarchal ideologies by appropriating her own voice and narrating her story" (ibid.: 124).

This leads us to a discussion of the role gender plays in constituting genre and, reflectively, how genre constitutes gender. Atwood has always engaged with feminist thought (Gwynn 2012: 333) and gender also plays a role in constituting genre in her work (Mattisson 2914: 229). Nischik (2009) examines the development of gender issues in Atwood's work from three perspectives: in a particular genre from the beginning of Atwood's career to its more recent stages, in gender-sensitive linguistic variants, and how these develop in a specific genre from Atwood's early work to more recent texts. Yet, Nischik stresses the author's disregard with feminist backlash culture that emerged in the post-feminist rhetoric of the 1980s, despite her obsession with themes and cultural contexts that are inseparable from post-feminist rhetoric, such as advertising and marketing strategies, the experience of the career woman, and reappraisals of female sexuality. What we ultimately come to acknowledge is that in Alias Grace Atwood explores the ways that consideration of gender and sexuality have led to the rethinking the subjectivity of working-class prejudice beyond only a socioeconomic category 
(Kumamoto-Stanley 2001: 373). In the novel, Atwood reviews the gender and class issues involved in the murder case where Grace is depicted as a 'murderess' and becomes the central topic for the public. This is a public related to Victorian ideology and particularly gender ideology, which proposed women should follow the "cult of true womanhood" (Xiaoxiao 2014: 173).

Instead of exposing the truth of the murder to Dr. Jordan, Grace tells him stories of lower-class women, such as her mother, Mary and Nancy, whose miserable experiences represent a criticism and irony against the hypocritical social and gender ideology. Grace's friend Mary's story is parallel to the experience of Nancy, another maidservant Grace worked with. Nancy, like Mary, become the object of sexual desire of males, but in slightly different terms because Mary had yielded to the seduction of and upper-class man. Nancy, on the other hand, seduced her master in hope of getting out of the underworld through marrying an upper-class man. Luckier than Mary, Nancy is endowed with more rights in the house and can dress up like a 'lady' (ibid.: 174). Unfortunately, Nancy is unable to shake off the role as transgressor (ibid.: 279), i.e. sexual prey hunted by Mr. Kinnear. In truth, Nancy was hired because of her loose morals which Mr. Kinnear wished to exploit. The double standards of the Victorian gender ideology are apparent in Mr. Kinnear and Nancy's relationship: he still gains some respect as a 'gentleman', while Nancy is despised by almost everyone at the local church. Their affair engenders repercussions in the community. When Nancy and Grace go to church on Sunday, most villagers shun them but, being in a position of spectator, Grace reveals her observation about social situations and comments the villagers' hypocrisy (Table 1$){ }^{26}$

\footnotetext{
${ }^{26}$ Text samples are referenced in terms of the episode in which they appear and at what time: e.g. @9:24 signifies that the text extract begins at 9 minutes and 24 seconds into the episode. Paralinguistic phenomena are indicated in uppercase letters in parentheses: (CHUCKLES). Salient contextual information in indicated in lowercase letters: (interior monologue). Salient features in text samples are indicated in bold: and their stories all prepared.
} 
Table 1: Episode 4 @9:24

\begin{tabular}{|c|c|}
\hline Speaker & Text \\
\hline $\begin{array}{c}\text { Minister } \\
\text { (we see Grace falling } \\
\text { asleep in the church, } \\
\text { sitting next to Mr. } \\
\text { Kinnear and Nancy) }\end{array}$ & $\begin{array}{l}\text { We will be saved by Divine Grace alone. } \\
\text { And no efforts on our part or any good works that we might do. }\end{array}$ \\
\hline $\begin{array}{c}\text { Female parishioner } \\
\text { (to another female } \\
\text { parishioner at her } \\
\text { side) }\end{array}$ & $\begin{array}{l}\text { (WHISPERS) } \\
\text { It's an outrage. } \\
\text { An outrage. }\end{array}$ \\
\hline $\begin{array}{c}\text { Nancy } \\
\text { (to Mr. Kinnear) }\end{array}$ & $\begin{array}{l}\text { Let's go. } \\
\text { I can't stand being stared at. }\end{array}$ \\
\hline $\begin{array}{c}\text { Grace } \\
\text { (interior monologue) }\end{array}$ & $\begin{array}{l}\text { I thought, these are cold and proud people and not good neighbors. } \\
\text { They are hypocrites, they think the church is a cage to keep God } \\
\text { in, so he will stay locked up there and not go wandering about } \\
\text { the Earth during the week poking His nose into their business } \\
\text { and looking into the depths and doubleness of their hearts and } \\
\text { lack of true charity. } \\
\text { They believe they need only be bothered about Him on Sundays } \\
\text { when they have their best clothes on and their faces straight, and } \\
\text { their hands washed and their gloves on, and their stories all } \\
\text { prepared. }\end{array}$ \\
\hline
\end{tabular}

This (Table 1) may be considered one of the rare moments of 'truth' with relation to Grace's narrative. She her clearly expresses how she feels of Victorian society of her time: "they think the church is a cage to keep God in, so he will stay locked up there and not go wandering about the Earth during the week poking His nose into their business and looking into the depths and doubleness of their hearts and lack of true charity". And, most telling, she adds that "their stories" are "all prepared". Is it not this insight that precisely leads Grace to somewhat 'doctor' her narrative for Dr. Jordon?

Atwood's novel continuously hides and reveals repressed desires that refuse to be denied. Another telling sign of patriarchal, Victorian society, which reduces female subjects to objects of the flesh, is Dr. Jordon's repeated fantasizing of Grace (Defalco 2006: 777). Even the highly gendered symbol of the quilt itself draws attention to the historic realities transforming women's bodies, from a birthing body to a corpse. Pregnancies, too, in Alias Grace are rarely brought to term successfully. Indeed, Mary's abortion, ultimately leading to her death, and Nancy's murder, constructed in the narrative as at least in part due to her transgressive pregnancy, emphasize the dangers of reproduction (ibid.: 779).

For Dr. Jordon, the body figures as an epistemological tool, aiding in the construction of meaning, and the apprehension of the sources of identity (ibid.: 780). Table 2 illustrates a moment of interior monologue on the part of Grace, at the end of one of her initial sessions with Dr. Jordon. 
Table 2: Episode $1 @ 42: 39$

\begin{tabular}{|c|l|}
\hline Speaker & \multicolumn{1}{c|}{ Text } \\
\hline $\begin{array}{c}\text { Grace } \\
\text { (interior monologue, as } \\
\text { she watches Dr. Jordon } \\
\text { taking notes during their } \\
\text { sessions, while she is } \\
\text { sewing) }\end{array}$ & $\begin{array}{l}\text { As long as I say something, anything at all, you smile and } \\
\text { write it down. } \\
\text { When you write, I feel as if you are drawing on me, drawing } \\
\text { on my skin with the feather end of an old-fashioned goose } \\
\text { pen. } \\
\text { As if hundreds of butterflies have settled all over my face } \\
\text { and are softly opening and closing their wings. }\end{array}$ \\
$\begin{array}{c}\text { But underneath that is another feeling, a feeling of being } \\
\text { wide-eyed awake and watchful. }\end{array}$ \\
$\begin{array}{c}\text { interior monologue, we her in bed being } \\
\text { touched by a hand, and } \\
\text { Dr. Jordon watching her) }\end{array}$ & $\begin{array}{l}\text { It's like being wakened suddenly in the middle of the night, } \\
\text { fast, and no one is there. }\end{array}$ \\
\hline $\begin{array}{c}\text { Grace } \\
\text { (interior monologue, we } \\
\text { see Grace in Dr. Jordon's } \\
\text { bedroom watching him) }\end{array}$ & $\begin{array}{l}\text { And underneath that is another feeling still, a feeling of being } \\
\text { torn open, not like a body of flesh, it is not painful as such, } \\
\text { but like a peach. } \\
\text { And not even torn open, but too ripe and splitting of its own } \\
\text { accord. } \\
\text { And inside the peach, there's a stone. }\end{array}$ \\
\hline
\end{tabular}

It is not surprising that Grace's first experience of Dr. Jordon's psychological investigation is manifested in a distinctly physical sensation (Table 2), as "a feeling of being torn open, not like a body of flesh, it is not painful as such, but like a peach. And not even torn open, but too ripe and splitting of its own accord." Nonetheless, at the end of the episode (which coincides with the text sample cited in Table 2), following her description of being laid bare during her encounters with Dr. Jordon, Grace also adds that "inside the peach, there's a stone", implying she has a will and that she may not succumb to Dr. Jordon's power over her.

Additionally, the feminine accessories present on the scenes during their encounters, that Dr. Jordon fully acknowledges and questions her about - needles, threads while Grace sews - suggest his feminization of the submissive, a process of gendering that facilitates the effective disavowal of the body as female, as 'other'. The pattern of what we might describe as 'carnification' in the novel is organized around gendered bodies, drawing attention to the patriarchal power dynamic implicit in the medical structuring of the body. There is a connection between the feminine and the body that is part of a long tradition of female objectification that facilitates, I dare add encourages, the transformation of the female subject into scant flesh and, at the same time, prevents any similar transformation of men (Defalco 2006: 781).

If taken one step further, distinguishing the female body as corpse, we can tap into numerous examples of cannibalistic images in Alias Grace that 
draw attention to gendered power relations. Remarks such as the male traveler with Grace in a buggy (as she travels to Mr. Kinnear's farm to take up Nancy's offer to work for him) that women are "better for a pinch of salt" (Table 3) depict women as tasty morsels, conflating cannibalistic desire and sexual innuendo.

Table 3: Episode 3 @ 17:57

\begin{tabular}{|c|l|}
\hline Speaker & \multicolumn{1}{c|}{ Text } \\
\hline $\begin{array}{c}\text { Grace } \\
\text { (interior monologue, she } \\
\text { is in a buggy) }\end{array}$ & $\begin{array}{l}\text { The journey up Yonge Street to Richmond Hill was more } \\
\text { uncomfortable than I expected. }\end{array}$ \\
\hline $\begin{array}{c}\text { Male traveler (farm hand) } \\
\text { in buggy }\end{array}$ & Never look behind you. \\
\hline Grace & Why not? \\
\hline $\begin{array}{c}\text { Male traveler (farm hand) } \\
\text { in buggy }\end{array}$ & $\begin{array}{l}\text { Because the past is the past and regret is vain. Let bygones be } \\
\text { bygones. } \\
\text { You know what became of Lot's wife turned to a pillar of salt, } \\
\text { she was. } \\
\text { Waste of a good woman. (CHUCKLES) Not that they aren't } \\
\text { all the better for a pinch of salt. }\end{array}$ \\
\hline
\end{tabular}

It is not only the outwardly brutish characters in the series that indulge in the transformation of women into gastronomic delights, though certainly the farm implements dealer and the male prison guards are good examples of sexual desire as cannibalistic (ibid.: 782). The upper-middle-class Dr. Jordon also indulges in cannibalistic sexual fantasies that equate sex and eating. These multiple, distinctly gendered, fantasies of consumption with the role of food and eating also appear in Atwood's previous works, reflecting a patriarchal, imperialistic culture based on greedy devouring. However, it needs to be pointed out that the desire to engulf in Alias Grace, particularly Dr. Jordon's desire, also creates the suggestion of sameness, that would ultimately threaten male identity.

Within the interdisciplinary field of feminist scholarship, the term gender stands for sexual identity as a social or cultural construct. Although Atwood has never defined herself as a feminist writer because of her conviction that a writer's work should remain outside all ideology, her writing offers feminist criticism invaluable material insofar as it is about female experience in Western patriarchal society from a specifically female point of view. Changing ideologies of gender assign different roles to men and women in different periods of history. Yet, the essential assumption of a hierarchical difference between the sexes, i.e. masculinity over femininity, seems to remain more or less constant (Özdemir 2003: 57).

Finally, the examination of gender identity in Alias Grace is largely based on a Lacanian-postmodern perspective, investigating the relationship of the unconscious and the symbolic construction of femininity, and the linguistic 
and discursive practices of the dominant culture (ibid.: 59). Lacan defines woman as "excluded by the nature of things which is the nature of words" (cited in Gilbert and Gubar 1989: 96). In Cornell and Thurschwell's rendering (1987: 143) of Lacan's idea, "Woman does not exist except as the other of a discourse grounded in her radical exclusion". However, femininity as a symbolic category should not be equated with actual women. Freud and Lacan teach us that there are no such things as 'men' and 'women'. As individuals we all have elements of both: women, as well as men, may be 'masculine' (ibid.: 151). At the same time the paradox for women is that they are in this fundamental sense expected to be masculine while being feminine by conforming to the norms of femininity. A further dilemma, I might add, is linked with the problematic nature of the imperative for women to identify with femininity, insomuch as it is a devalued and repressed term of patriarchy.

\section{Findings}

This section presents findings from our corpus-driven approach. Table 4 lists pronouns extracted from the processing of scripts using Sketch Engine. The table highlights in bold the frequency of marked lexis in relation to the list of average frequency calculated for all 6 episodes (also indicated in bold) of each lexical item. The table indicates episodes along the first row as AG (Alias Grace) followed by the number of each episode. We shall use this system to refer to specific episodes. Marked pronouns are further specified with an arrow: 'I', 'their' and 'he' emerge as being marked in AG5.

Table 4: Pronoun wordlists

\begin{tabular}{|l|r|r|r|r|r|r|r|r|}
\hline Episodes & AG 1 & AG 2 & AG 3 & AG 4 & AG 5 & AG 6 & Average & ALL \\
\hline Pronouns & & & & & & & & \\
\hline I & 185 & 161 & 189 & 198 & $\mathbf{2 2 7}$ & 207 & $\mathbf{1 9 5}$ & 1,167 \\
\hline My & 37 & 31 & 28 & 31 & 24 & 34 & $\mathbf{3 1}$ & 185 \\
\hline Myself & 6 & 8 & 7 & 9 & 5 & 6 & $\mathbf{7}$ & 41 \\
\hline You & 154 & 161 & 148 & 195 & 159 & 165 & $\mathbf{1 6 4}$ & 982 \\
\hline Your & 35 & 16 & 29 & 33 & 28 & 28 & $\mathbf{2 8}$ & 169 \\
\hline We & 32 & 38 & 19 & 25 & 43 & 25 & $\mathbf{3 0}$ & 182 \\
\hline Us & 9 & 9 & 2 & 4 & 9 & 6 & $\mathbf{7}$ & 39 \\
\hline Our & 8 & 15 & 4 & 7 & 7 & 5 & $\mathbf{8}$ & 46 \\
\hline They & 41 & 23 & 28 & 26 & 22 & 19 & $\mathbf{2 7}$ & 159 \\
\hline Their & 4 & 7 & 3 & 13 & $\mathbf{2 2}$ & 5 & $\mathbf{9}$ & 54 \\
\hline She & 29 & 21 & 34 & 24 & 39 & 43 & $\mathbf{3 2}$ & 190 \\
\hline He & 30 & 39 & 39 & 34 & $\mathbf{7 3}$ & 19 & $\mathbf{3 9}$ & 234 \\
\hline
\end{tabular}

Episode 5 represents a typical 'he-said-she-said' case where the presence of multiple 'others' surround Grace and hence the high number of the pronoun 'their'. These 'others' include: Jeremiah (who Grace had once met but now introduced himself as Dr. Dupont), a 'neuro-hypnotist' who had arrived at the Governor's mansion and suggested putting Grace into a trance 
to try and access her memories; Dr. Jordan; Grace's deceased friend Mary who visits her, whispering messages; and, lastly, Grace herself pondering her contradictory statements and her trial while musing about what she should tell Dr. Jordan about the day of the murders.

In this episode, too, we find a preponderance of the pronoun 'he' (Table 4) which is ascribable to the men surrounding her life: McDermott who allegedly, with Grace, murdered the two victims Nancy and Mr. Kinnear and who - in one of Grace's possible accounts of the occurrences - offered to marry her if she would help him murder the two victims; Jeremiah (the then Dr. Dupont), who Grace had took kindly to prior to the events for which she was imprisoned and sent to asylums.

Episode 5 also presents an overwhelming use of the pronoun 'I' (Table 4). This is plausible if we consider Grace's discernment in relation to the numerous 'others' as described above and to the various male 'others' present in this episode. Indeed, this episode may be considered as announcing, and leading to, the denouement of the series, the final part of the narrative where the different strands of the plot are drawn together. Further, as found in previous work (Monacelli 2004, 2018b), these patterns of repetition thus point to the discourse structure of the text in the TV miniseries Alias Grace.

\section{Discussion and concluding remarks}

This paper reports on findings from a qualitative (corpus-driven) and qualitative (discourse analytical) approach to the analysis of TV miniseries Alias Grace, adapted from Margaret Atwood's novel (1996). Findings reveal pronouns 'I', 'their', and 'he' in episode 5 of the miniseries highly correlate with both the distinction of gender and social class. These patterns of repetition are also indicative of the discourse structure of the TV miniseries Alias Grace, as shown in $\$ 4$. We have argued elsewhere (Monacelli 2018a) that mood and modality play an important role in Alias Grace in terms of understanding, and distinguishing, elements of truth in Grace Mark's narrative in relation to her role in the murders of Dr. Kinnear and Nancy. Through the contribution of these two analyses, pronominal reference and mood and modality, it was possible to fully comprehend the ambiguity of the miniseries narrative.

Throughout both Atwood's novel and the TV miniseries, we follow Grace in her revelation to readers and viewers of events as she recalls them during her sessions with Dr. Jordon, who was tasked with understanding whether Grace was afflicted by madness or whether she was a cold-blooded 'murderess', the everyone thought her to be. The level of ambiguity throughout the narrative in both the novel and the miniseries leaves readers and viewers at bay as to her innocence. We feel that only through a linguistic microanalysis is it possible to discern how events surrounding the murders came about while, at the same time, understanding the nature of the ambiguity 
itself in the narrative, in relation to gender politics and social class in Victorian society in Canada during that time.

It would be of interest to extend these analyses to other, similar, piece periods, in order to tease out the underlying motives for developing storylines in relation to historical contexts in relation to gender politics and social class. This would make it possible to delineate the turn of specific perspectives in societal norms and, at the same time, also reveal how current events develop, when compared to historical contexts.

\section{References:}

1. Atwood, M. (1996). Alias Grace. Toronto: McClelland \& Stewart Inc.

2. Bluestone, G. (2003) Novels into Film. Baltimore, MD: John Hopkins University Press.

3. Bondi, M. (2010) Perspectives on key words and keyness: An introduction, in M. Bondi and M. Scott (eds.) Keyness in Texts. Amsterdam/Philadelphia: John Benjamins, 1-18.

4. Chilton, P. (2004) Analysing Political Discourse. Theory and Practice. London/New York: Routledge.

5. Chilton, P. and Schäffner, C. (1997) Discourse and Politics, in T. A. Van Dijk (ed.) Discourse as Social Interaction. London: Sage, 206230.

6. Cornell, D. and Thurschwell, A. (1987) Feminism, Negativity, Intersubjectivity, in Feminism as Critique, C. Belsey and J. Moore (eds.). Basingstoke: Macmillan, 143-162.

7. Defalco, A. (2006) Haunting Physicality: Corpses, Cannibalism, and Carnality in Margaret Atwood's Alias Grace, University of Toronto Quarterly, Vol. 75 No. 2 771-785.

8. Desmond, J. and Hawkes (2015) Adaptation: Studying Film and Literature, New York: McGraw Hill.

9. During, D. (1980) Foucault and Literature. London: Routledge.

10. Fairclough, N. (2003) Analysing Discourse: Textual Analysis for Social Research. London: Routledge.

11. Felski, F. (1989) Beyond Feminist Aesthetics: Feminist Literature and Social Change. Cambridge, MA.: Harvard University Press.

12. Fillmore, C. J. (1997) Lectures on Deixis. Stanford: CSLI Publications.

13. Garzone, G. (2002) Quality and norms in interpretation, in G. Garzone and M. Viezzi (eds.) Interpreting in the 21st Century: Challenges and opportunities. Amsterdam and Philadelphia: John Benjamins, 107119.

14. Gilbert, S. M. and Gubar, S. (1989) Sexual Linguistics: Gender, Language, Sexuality', in The Feminist Reader: Essays in Gender and 
the Politics of Literary Criticism, C. Belsey and J. Moore (eds.). Basingstoke: Macmillan, 81-99.

15. Groom, N. (2010) Closed-class keywords and corpus-driven discourse analysis, in M. Bondi and M. Scott (eds.) Keyness in Texts. Amsterdam/Philadelphia: John Benjamins, 59-78.

16. Gwynne, J. (2012) Engendering Genre: The works of Margaret Atwood, Journal of Postcolonial Writing, Vol. 48, No. 3, 332-333.

17. Hatim B. and Mason I. (1997) The Translator as Communicator, London/New York, Routledge.

18. Ingersoll, E. G. (2001) Engendering Metafiction: Textuality and closure in Margaret Atwood's Alias Grace, American Review of Canadian Studies, Vol. 31 No. 3, 385-401.

19. Irshad, M. S. and Gaur, R. (2013) Construction of Sex, Gender and Class in Margaret Atwood's Alias Grace, International Journal of English and Literature (IJEL), Vol. 3 No. 2, 117-126.

20. Kumamoto-Stanley, S. (2003) The Eroticism of Class and the Enigma of Margaret Atwood's Alias Grace, Tulsa Studies in Women's Literature, Vol. 22 No. 2, 2003, 371-386.

21. Malone, M. J. (1997) Worlds of Talk: The Presentation of Self in Everyday Conversation. Malden, MA/Cambridge: Polity Press.

22. Mattisson, J. (2014) Engendering Genre: The Works of Margaret Atwood, English Studies, Vol. 95 No. 2, 228-229.

23. Monacelli, C. (2018a) The Language of Truth, Memory and Madness in Margaret Atwood's Alias Grace, in International Journal of Social Science and Humanities Research (IJSSHR), Vol. 6 No. 4, 613-622.

24. Monacelli, C. (2018b) Race, Gender and Social Class in TV series Scandal: Patterns of repetition, pronominal reference and refraction, in International Journal of Novel Research in Humanity and Social Sciences (IJSSHR), Vol. 5 No. 4, 19-29.

25. Monacelli, C. (2004) A Tightrope with a Net. Meta, Vol. 49 No. 4, 891-909.

26. Nichik. R. M. (2009) Engendering Genre: The Works of Margaret Atwood. Ottawa: University of Ottawa Press.

27. Özdemir, E. (2003) Power, Madness, And Gender Identity In Margaret Atwood's Surfacing: A feminist reading, English Studies, Vol. 84 No.1, 57-79.

28. Pratt, A. (1981) Archetypal Patterns in Women's Fiction, Bloomington: Indiana University Press.

29. Sontag, S. (1977) Illness as Metaphor. New York: Vintage.

30. Stubbs, M. (2010) Three Concepts of Keywords, in M. Bondi and M. Scott (eds.) Keyness in Texts. Amsterdam/Philadelphia: John Benjamins, 21-42. 
31. Ting-Toomey, S. and A. Kurogi 1998. "Facework competence in intercultural conflict: An up- dated face-negotiation theory." International Journal of Intercultural Relations, Vol. 22 No. 2, 187-225.

32. Van Dijk, T.A. (2001) Multidisciplinary CDA: A Plea for Diversity, in R. Wodak and M. Meyer (eds.) Methods of Critical Discourse Analysis. London: Sage, 95-120.

33. Xiaoxiao, L. (2014) The Social Critical Function of Female Discourse in Alias Grace, Studies in Literature and Language, Vol. 9 No. 3,173176. 